\title{
The effect of propagation term and method on the growth and fresh herb productivity of sage and balm cultivated in pots
}

Ewa Capecka

Department of Vegetable and Medicinal Plants University of Agriculture in Krakow 29 Listopada 54, 31-425 Kraków, Poland

\begin{abstract}
The growing of sage (Salvia officinalis L.) and balm (Melissa officinalis L.) in pots for the purpose of obtaining fresh culinary herbs was conducted during four terms from spring to autumn. The objective was to determine the possibility of using stem cuttings taken at different developmental stages of the mother plants and to compare this method of plant propagation with that based on seeds. The period of sage growth was shorter when it was raised from cuttings than from seeds. In the case of balm, the use of cuttings was more effective than generative propagation in the period from summer to autumn. In both species, the best results of rooting were achieved when cuttings were taken before plant flowering in spring and after flowering in August. The poorest balm rooting was recorded when taking cuttings at plant flowering, and at flowering and after flowering in July for sage.
\end{abstract}

Key words: cuttings, growing term, herb mass, Melissa officinalis, production period, Salvia officinalis, seeds

\section{INTRODUCTION}

The incorporation of fresh herbs into foods has become more and more popular amongst consumers due to their growing expectation of the richness of flavour in everyday meals. Sensory impressions connected with fresh and dried herbs are often otherwise, which results from differences in quality and quantity of specific chemical compounds determining taste and aroma (Jambor and Czosnowska 2001, UNIDO 2006). Fresh herbs, as leafy plant parts, sustain their quality for a very short time after cutting (Cantwell and Reid 1992). The rapid deterioration of cut herb is avoidable by providing potted plants to wholesale and retail points. In this way, consumers can also make the best of a herbal plant whenever they like.

The growing of herbs in pots is based first of all on the practice of producers (Metera 1984) who prefer fast and low-cost methods of obtaining marketable produce. Fresh herbs in pots should be delivered to the market in relatively small batches, but continuously. Such herbs as basil, balm, oregano, rosemary, sage and thyme are raised in pots from seeds. During the vegetation season, stem cuttings from these plants may be applied as propagation materials. During some parts of the year, such a method of fresh herb production in pots may be faster than from seeds (Metera 1984, Kaçar et al. 2009). The degree of rooting and period 
of time necessary for proper root formation from cuttings depend on the date of their taking and the stage of mother plant development (Retournard 1992, ANPSA 2006).

The objective of this work was to determine the effectiveness of applying stem cuttings taken at several developmental stages of sage and balm mother plants to produce fresh herbs in pots and to compare this growing method with that of seedbased growing.

\section{MATERIAL AND METHODS}

The experiment concerning the growing of common sage (Salvia officinalis L.) and lemon balm (Melissa officinalis L.) in pots was conducted in the greenhouse and cold frames of the University of Agriculture in Kraków in the years 1999 and 2000. Plants were propagated generatively and vegetatively. Seeds came from the Herbador company in Bydgoszcz. For vegetative propagation, stem cuttings were taken from mother plants in the third year of their cultivation in the open field. Cuttings were taken at the following times:

I - the beginning of plant vegetation, before flowering (sage - second ten days of May, balm - at the turn of April and May);

II - full plant vegetation, during flowering (sage - first ten days of June, balm third ten days of June);

III - full plant vegetation, after flowering (third ten days of July);

IV - end of plant vegetation (third ten days of August).

Stem cuttings 7-8 $\mathrm{cm}$ in length, with three pairs of fully developed leaves, were used each time. In terms I, III, and IV, these were softwood apical cuttings. In term II, upper parts with flowers or flower buds were removed and the cuttings taken were deprived of apical buds. In terms III and IV, cuttings came from shoots grown from plants cut down at the stage of flowering in such a way that two pairs of properly developed, healthy leaves remained on the stems.

The rooting of cuttings and seed sowing were conducted in a nursery of a non-heated glasshouse, where the mean temperature ranged from 16 to $25^{\circ} \mathrm{C}$ in the spring and autumn and from 20 to $28^{\circ} \mathrm{C}$ in the summer. After removing a pair of leaves at their base, cuttings numbering 1,600 per $\mathrm{m}^{2}$ were placed at a depth of about $3 \mathrm{~cm}$ into $10 \mathrm{~cm}$ deep plastic boxes filled with a mixture of perlite and fine peat moss $(2: 1, \mathrm{pH} 6.5)$ and kept under high relative air humidity. At the same time, seeds of the tested species were sown in boxes filled with peat moss substrate, where seedlings were raised until they reached a height of about $2 \mathrm{~cm}$. On the $15^{\text {th }}$ day after the placement of cuttings in the rooting medium, the daily inspection of root formation began. An increase in the colour intensity of the cuttings testified to the proper development of their roots and determined their removal from the rooting medium for inspection (number of rooted cuttings, length and diameter of root system).

Three each of seedlings and rooted cuttings were transplanted into pots $11 \mathrm{~cm}$ in diameter, filled with peat moss substrate (pH 6.4, $700 \mathrm{mg} \mathrm{N}, 150 \mathrm{mg} \mathrm{P}$, $750 \mathrm{mg} \mathrm{K}, 2000 \mathrm{mg} \mathrm{Ca}, 200 \mathrm{mg} \mathrm{Mg}$ per $1 \mathrm{dm}^{3}$ ). After a week of adaptation, the potted plants were transferred outside from the glasshouse into cold frames, where they were inspected and irrigated regularly until they reached marketable value, i.e. at least two pairs of lateral shoots were formed and the above-ground parts were abundant enough to permit cutting for culinary purposes. Afterwards, a visual evaluation on a 2-5-point scale $(2-$ the worst, 5 - the best) was conducted and then the plant height, shoot number per plant and cut herb mass were measured.

The experiment was carried out in four replications with 100 cuttings (to be rooted) of each tested species and growing term and 15 pots (with three rooted cuttings or seedlings) per replication. For statistical verification, the analysis of variance and Tukey t-test were applied. One-way ANOVA was used to determine the effect of growing term on the degree of rooting of the cuttings, while twoway ANOVA was used to compare the effects of generative and vegetative propagation in the tested growing terms. The results presented are the means of the two observation years.

\section{RESULTS AND DISCUSSION}

Common sage and lemon balm are species of good quality sowing material (Takano et al. 1993). DeBaggio (1987) reported that 17 and 11 days passed from seed germination to plant transplantation into pots in the case of sage and balm, respectively. Despite an even and relatively quick emergence noted in the present experiment (six days for balm, eight days for sage), the initial growth of seedlings was slow, especially in the second half of summer (Tab. 1). According to Davis (1997) and Nicola et al. (2005), the vegetative propagation of these herbs allowed for a shortening of the growing cycle. In the present investigation, the period of marketable herb 
Table 1. Number of days between taking cuttings or sowing seeds and transplantation into pots and obtaining marketable herb of sage and balm in pots depending on the term and method of plant propagation (mean for two years)

\begin{tabular}{|c|c|c|c|c|c|c|c|}
\hline & \multirow{2}{*}{ Term } & \multicolumn{3}{|c|}{ Days before transplanting into pots } & \multicolumn{3}{|c|}{ Days before obtaining marketable herb in pots } \\
\hline & & cuttings & sowing & mean & cuttings & sowing & mean \\
\hline \multirow{5}{*}{ Sage } & $\mathrm{I}$ & 22 & 21 & 21 & 53 & 68 & 61 \\
\hline & II & 23 & 25 & 24 & 57 & 65 & 61 \\
\hline & III & 24 & 25 & 24 & 58 & 68 & 63 \\
\hline & IV & 28 & 30 & 29 & 60 & 75 & 67 \\
\hline & mean & 24 & 25 & & 57 & 69 & \\
\hline \multirow{5}{*}{ Balm } & I & 25 & 17 & 21 & 43 & 45 & 44 \\
\hline & II & 25 & 20 & 23 & 54 & 50 & 52 \\
\hline & III & 24 & 24 & 24 & 49 & 68 & 59 \\
\hline & IV & 30 & 27 & 29 & 61 & 72 & 67 \\
\hline & mean & 26 & 22 & & 52 & 59 & \\
\hline
\end{tabular}

production was shorter when started from cuttings than when started from seeds - by 12 and seven days for sage and balm, respectively. Regardless of the plant propagation method, the later the term of cultivation, the longer the period of obtaining marketable sage and balm herb.

The effectiveness of rooting depended on the period when cuttings were taken (Tab. 2). The best results were recorded when they were taken from plants in the stage of vegetative growth in the spring and at the end of summer. The ability of plant parts to form roots is determined in a high degree by the phase of development of the mother plants and stages of generative growth are considered the least suitable for propagation by cuttings (Janick 1986, Retournard 1992, Hartmann and Kester 2009). This was obviously reflected in the present results. The smallest percentage of rooting balm was observed when cuttings were taken during flowering (term II), while for sage it was the case both during and after flowering (terms II and III). The dimensions of the root system of balm cuttings depended on the terms when they were taken, similarly to the percentage of rooting. For sage cuttings taken in the I term, despite a good percentage of rooting, the length and diameter of the root system were smaller than in the following three terms when, apart from differences in the degree of rooting, sage cuttings formed root systems of the same dimensions. The effectiveness of sage propagation by stem cuttings was stressed by Kaçar et al. (2009), who evidenced both very good rooting (exceeding $72 \%$ ) and a high dry weight of formed roots.

The traits describing plants at harvest maturity are given in Table 3. For sage grown from seeds, the best results of plant height and branching as well as herb mass were recorded in terms I and II. The seedlings grew considerably slower during the next two terms. In the case of vegetative sage propagation, the highest plants with the greatest number of lateral shoots and herb masses were observed in terms I and III. The unfavourable effect of term II on the rooting of cuttings persisted during their subsequent growth after transplantation into

Table 2. Results of rooting cuttings of sage and balm depending on the term in which they were taken (mean for two years)

\begin{tabular}{ccccc}
\hline & Term & Number of rooted cuttings (\%) & Diameter of root system $(\mathrm{cm})$ & Length of root system $(\mathrm{cm})$ \\
\hline \multirow{4}{*}{ Sage } & I & $59 \mathrm{~b}^{*}$ & $2.2 \mathrm{a}$ & $6.5 \mathrm{a}$ \\
& II & $43 \mathrm{a}$ & $2.9 \mathrm{~b}$ & $8.0 \mathrm{ab}$ \\
& III & $35 \mathrm{a}$ & $2.7 \mathrm{~b}$ & $8.3 \mathrm{~b}$ \\
& IV & $62 \mathrm{~b}$ & $3.0 \mathrm{~b}$ & $8.4 \mathrm{~b}$ \\
\hline \multirow{3}{*}{ Balm } & I & $100 \mathrm{c}$ & $3.5 \mathrm{~b}$ & $14.1 \mathrm{~b}$ \\
& II & $17 \mathrm{a}$ & $2.1 \mathrm{a}$ & $10.5 \mathrm{a}$ \\
& III & $67 \mathrm{~b}$ & $2.5 \mathrm{a}$ & $13.1 \mathrm{~b}$ \\
& IV & $100 \mathrm{c}$ & $4.1 \mathrm{c}$ & $13.6 \mathrm{~b}$ \\
\hline
\end{tabular}

*Values marked with the same letters do not differ significantly at $\mathrm{p}=0.05$ 
Table 3. Morphological characteristics and visual evaluation of sage and balm at marketable maturity depending on the term and method of plant propagation (mean for two years)

\begin{tabular}{cccccccccc}
\hline & & \multicolumn{2}{c}{ Plant height $(\mathrm{cm})$} & \multicolumn{2}{c}{$\begin{array}{c}\text { Number of pairs } \\
\text { of lateral shoots }\end{array}$} & $\begin{array}{c}\text { Score of visual evaluation } \\
\text { (scale 2-5) }\end{array}$ & Mass of herb per pot (g) \\
\cline { 3 - 11 } & Term & cuttings & sowing & cuttings & sowing & cuttings & sowing & cuttings & sowing \\
\hline \multirow{3}{*}{ Sage } & I & $15.1 \mathrm{c}^{*}$ & $13.9 \mathrm{c}$ & $5.2 \mathrm{c}$ & $3.7 \mathrm{~b}$ & $4.0 \mathrm{~b}$ & $4.5 \mathrm{~b}$ & $32.0 \mathrm{c}$ & $27.3 \mathrm{~b}$ \\
& II & $11.1 \mathrm{ab}$ & $15.2 \mathrm{c}$ & $3.3 \mathrm{ab}$ & $3.4 \mathrm{~b}$ & $3.0 \mathrm{a}$ & $4.4 \mathrm{~b}$ & $25.7 \mathrm{~b}$ & $24.7 \mathrm{~b}$ \\
& III & $14.0 \mathrm{bc}$ & $8.2 \mathrm{~b}$ & $4.1 \mathrm{~b}$ & $4.0 \mathrm{~b}$ & $3.9 \mathrm{~b}$ & $4.3 \mathrm{~b}$ & $27.8 \mathrm{bc}$ & $14.2 \mathrm{a}$ \\
& IV & $8.2 \mathrm{a}$ & $4.8 \mathrm{a}$ & $2.8 \mathrm{a}$ & $1.8 \mathrm{a}$ & $4.5 \mathrm{c}$ & $3.8 \mathrm{a}$ & $18.6 \mathrm{a}$ & $9.1 \mathrm{a}$ \\
\hline \multirow{4}{*}{ Balm } & mean & $12.1 \mathrm{~B} *$ & $10.5 \mathrm{~A}$ & 3.9 & 3.2 & 3.9 & 4.3 & $26.0 \mathrm{~B}$ & $18.8 \mathrm{~A}$ \\
\hline & I & $13.5 \mathrm{~b}$ & $12.1 \mathrm{~b}$ & $5.5 \mathrm{c}$ & $5.8 \mathrm{c}$ & $5.0 \mathrm{c}$ & $5.0 \mathrm{c}$ & $16.5 \mathrm{bc}$ & $15.1 \mathrm{~b}$ \\
& II & $15.2 \mathrm{~b}$ & $13.8 \mathrm{~b}$ & $3.4 \mathrm{~b}$ & $4.9 \mathrm{c}$ & $3.6 \mathrm{a}$ & $4.8 \mathrm{bc}$ & $19.0 \mathrm{c}$ & $14.4 \mathrm{~b}$ \\
& III & $13.2 \mathrm{~b}$ & $10.8 \mathrm{~b}$ & $3.6 \mathrm{~b}$ & $3.9 \mathrm{~b}$ & $4.1 \mathrm{~b}$ & $4.5 \mathrm{ab}$ & $13.8 \mathrm{ab}$ & $8.5 \mathrm{a}$ \\
& IV & $7.2 \mathrm{a}$ & $6.1 \mathrm{a}$ & $2.3 \mathrm{a}$ & $2.1 \mathrm{a}$ & $4.9 \mathrm{c}$ & $4.3 \mathrm{a}$ & $13.0 \mathrm{a}$ & $7.2 \mathrm{a}$ \\
\hline
\end{tabular}

*Values marked with the same letters do not differ significantly at $\mathrm{p}=0.05$; small letters mark significance of plant propagation term, capital letters mark significance of propagation method

pots, which was reflected in the low estimation of the obtained plants. The highest visual evaluation score was recorded for the sage grown from cuttings in the last (IV) term of growing, when the increment of herb mass, though significantly smaller than in the earlier terms, guaranteed that there were twice as many above-ground parts than in the seedgrown sage. In the case of balm, the vegetatively propagated plants were higher and produced greater masses of herb than those propagated generatively. While investigating the effect of balm propagation method on yield under field conditions, Saglam et al. (2004) obtained better results using seedlings than cuttings. The total crop of plants raised from seeds was greater than from cuttings; nevertheless, this resulted from the more intense growth of the former in the second vegetation year. In the first year, the mass of the herb obtained from plants propagated with those two methods did not differ. The greater herb mass of balm propagated by cuttings than by seeds determined in the present study confirms that in the early period of development, seedlings of certain plants, herb species particularly, grow slowly and the mass increase of plants developing from cuttings is faster (Metera 1984, Janick 1986). This phenomenon may be advantageous for producers of potted herbs, especially in such terms of the year when vegetative plant material is easily available and the amount of labour connected with vegetative propagation can be compensated by the shortened production period and good quality of produce. The present study proved that in the subsequent growing terms from spring to autumn, the plant height, number of shoots, herb mass and visual evaluation score decreased, which for the seedgrown balm was more regular than for the balm from the cuttings. In the II term, the plants that were propagated vegetatively, though reaching the same height and gaining a similar herb mass as in the I term, formed fewer shoots and young leaves, which resulted in the low estimation of their appearance. The poor effects of rooting cuttings taken in that time (stage of plant flowering) in parallel with the very good results of the seed-grown plants indicated that generative balm propagation was more favourable in the II term (early summer). In early spring (term I), stem cuttings and seed sowing brought about similar results, but in late summer and autumn balm production in pots begun from stem cuttings rather than seeds is recommended.

\section{CONCLUSIONS}

1. The production of fresh culinary herb of common sage in pots with the use of stem cuttings as a source of propagation material was shorter than in the case of using seeds, irrespective of the growing term.

2. In the second half of summer, the growth of lemon balm in pots from stem cuttings is recommended over that from seeds, due to faster and more intense plant growth.

3. In the case of both tested species, the best results of rooting from stem cuttings were noted in the beginning and end of mother plant vegetation. The worst results of rooting in the case of balm were observed during mother plant flowering, 
and both during and after flowering in the case of sage.

\section{REFERENCES}

ANPSA, 2006. The Mint Bush Family - Propagation. Available online at http://anpsa.org.au/mints2.html; cited on 12 Feb 2006.

Cantwell M., Reid M.S., 1992. Postharvest handling systems: Fresh herbs. In: "Postharvest Technology of Horticultural Crops". A.A. Kader (ed.), Univ. California, Div. Agric. Nat. Res., Publ. 3311: 211-213.

DAvis M.J., 1997. Lemon balm. North Carolina Cooperative Extension Service.

DeBagGio T., 1987. Fast-cropping perennial potted herbs from seed: As easy as annuals but some cautions apply. The Herb, Spice, and Medicinal Plant Digest 5(4): 5-6.

Hartmann H.T., Kester D.E., 2002. Hartmann and Kester's plant propagation: principles and practice. $7^{\text {th }}$ ed. Prentice Hall.

Jambor J., Czosnowska E., 2001. Preparaty ze świeżych roślin. Post. Fitoter. 8: 1-4.

JANICK J., 1986. Horticultural Science. W.H. Freeman and Company, New York.

KaÇAR O., AZKAn N., ÇÖPLÜ N., 2009. Effects of different rooting media and indole butyric acid on rooting of stem cuttings in sage (Salvia officinalis L. and Salvia triloba L.). J. Food Agric. Environ. 7(3-4): 349-352.

Metera P., 1984. Zioła w doniczkach. Inst. Wyd. Związków Zawodowych, Warszawa.

Nicola S., Fontana E., Hoeberechts J., Saglietti D., 2005. Rooting products and cutting timing on sage (Salvia officinalis L.) propagation. Acta Hort. 676(2): 135-141.

Retournard D., 1992. Rozmnażanie 250 roślin przez sadzonki. Delta W-Z, Warszawa.

Saglam C., Atakisi I., Turhan H., Kaba S., Arslanoglu F., Onemli F., 2004. Effect of propagation method, plant density, and age on lemon balm (Melissa officinalis) herb and oil yield. New Zeal. J. Crop Hort. Sci. 32: 419-423.

UNIDO, 2006. Quality of dried foods and deteriorative reactions during drying. Chapter 31. Available online at http://www.unido.org/doc/32067; cited on 27 Aug 2006.

Takano T., Palevitch D., Simon J.E., Mathe A., 1993. Germination characteristics of herbs in Labiatae. Acta Hort. 331: 275-286.

\section{WPEYW TERMINU I SPOSOBU ROZMNAŻANIA NA WZROST ORAZ PRODUKTYWNOŚĆ ZIELA SZAŁWII LEKARSKIEJ I MELISY LEKARSKIEJ UPRAWIANYCH W DONICZKACH}

Streszczenie: W czterech terminach w okresie od wiosny do jesieni prowadzono doniczkowa uprawę szałwii lekarskiej i melisy lekarskiej z przeznaczeniem na świeże ziele przyprawowe. Celem pracy było ustalenie efektywności użycia sadzonek pędowych pobieranych w różnych fazach rozwoju roślin matecznych i porównanie tej metody uzyskiwania materiału do obsadzania doniczek z rozmnażaniem generatywnym. Okres uprawy szałwii w doniczkach był krótszy, gdy rozmnażano ją wegetatywnie, niż gdy stosowano wysiew nasion. W przypadku melisy wykorzystanie sadzonek pędowych było bardziej efektywne niż użycie nasion w okresie od lata do jesieni. Pod względem stopnia ukorzenienia sadzonek obu gatunków najlepsze rezultaty osiagnnięto pobierając je przed kwitnieniem roślin wiosną oraz po kwitnieniu w końcu sierpnia. Najgorszy wynik sadzonkowania melisy uzyskano podczas kwitnienia, a szałwii podczas kwitnienia i po kwitnieniu. 